\section{( OPEN ACCESS}

\title{
Relationship between changes in haemoglobin mass and maximal oxygen uptake after hypoxic exposure
}

\author{
Philo U Saunders, ${ }^{1,2}$ Laura A Garvican-Lewis, ${ }^{1,2}$ Walter F Schmidt, ${ }^{3}$ \\ Christopher J Gore ${ }^{1,2,4}$
}

'Department of Physiology, Australian Institute of Sport, Canberra, Australian Capital Territory, Australia ${ }^{2}$ National Institute of Sports Studies, University of Canberra, Canberra, Australian Capital Territory, Australia ${ }^{3}$ Department of Sports Medicine, University of Bayreuth, Bayreuth, Germany ${ }^{4}$ Exercise Physiology Laboratory, Flinders University, Adelaide, South Australia, Australia

\section{Correspondence to} Dr Philo U Saunders, Australian Institute of Sport, PO Box 176, Belconnen, ACT 2616, Australia;

philo.saunders@ausport.gov.au

Received 1 July 2013

Revised 27 August 2013

Accepted 12 September 2013

\begin{abstract}
Background Endurance athletes have been using altitude training for decades to improve near sea-level performance. The predominant mechanism is thought to be accelerated erythropoiesis increasing haemoglobin mass $\left(\mathrm{Hb}_{\text {mass }}\right)$ resulting in a greater maximal oxygen uptake $\left(\dot{\mathrm{VO}}_{2 \text { max }}\right)$. Not all studies have shown a proportionate increase in $\dot{\mathrm{V}} \mathrm{O}_{2 \max }$ as a result of increased $\mathrm{Hb}_{\text {mass. }}$. The aim of this study was to determine the relationship between the two parameters in a large group of endurance athletes after altitude training. Methods 145 elite endurance athletes (94 male and 51 female) who participated in various altitude studies as altitude or control participants were used for the analysis. Participants performed $\mathrm{Hb}_{\text {mass }}$ and $\dot{\mathrm{V}}_{2 \max }$ testing before and after intervention.
\end{abstract}

Results For the pooled data, the correlation between per cent change in $\mathrm{Hb}_{\text {mass }}$ and per cent change in $\dot{\mathrm{V}} \mathrm{O}_{2 \max }$ was significant $\left(p<0.0001, \mathrm{r}^{2}=0.15\right)$, with a slope $(95 \% \mathrm{Cl})$ of $0.48(0.30$ to 0.67$)$ intercept free to vary and 0.62 (0.46 to 0.77$)$ when constrained through the origin. When separated, the correlations were significant for the altitude and control groups, with the correlation being stronger for the altitude group (slope of 0.57 to 0.72 ).

Conclusions With high statistical power, we conclude that altitude training of endurance athletes will result in an increase in $\dot{\mathrm{V}} \mathrm{O}_{2 \max }$ of more than half the magnitude of the increase in $\mathrm{Hb}_{\text {mass, }}$ which supports the use of altitude training by athletes. But race performance is not perfectly related to relative $\dot{\mathrm{V}} \mathrm{O}_{2 \max }$, and other nonhaematological factors altered from altitude training, such as running economy and lactate threshold, may also be beneficial to performance.

\section{INTRODUCTION}

The effects of training at moderate altitude on subsequent performance at altitude and near sea-level became important at the 1968 Mexico City Olympic Games $(2300 \mathrm{~m})$, and has subsequently been researched extensively. It is now common practice for elite endurance athletes across a range of sports to use altitude training to improve performance near sea-level. The prevailing paradigm of adaptation to hypoxia is that the lower partial pressure of oxygen associated with moderate altitude induces erythropoietin (EPO) production in the kidneys, which in turn stimulates the production of red blood cells in the bone marrow, facilitating an increase in maximal oxygen uptake $\left(\mathrm{VO}_{2 \max }\right)$ and potentially improving endurance performance. ${ }^{1-3}$ Since $\mathrm{VO}_{2 \max }$ depends on cardiac output and the arteriovenous $\mathrm{O}_{2}$ difference, all factors that influence these physiological capacities may exert limiting effects on endurance capacity. ${ }^{4}$ The most important factor related to blood supply is the total blood volume, which may limit venous return and thus the stroke volume, as well as haemoglobin mass $\left(\mathrm{Hb}_{\text {mass }}\right)$, which along with the capacity of muscles to extract and use $\mathrm{O}_{2}$ determines the $\mathrm{O}_{2}$-transport capacity and therefore the arteriovenous $\mathrm{O}_{2}$ difference. ${ }^{5}$

Although some authors have explicitly related the change in near sea-level performance after an altitude training camp (hypoxic intervention) to the change in serum EPO ${ }^{12}$ at altitude, the correlation for the change in $\dot{\mathrm{VO}}_{2 \max }$ versus the change in red blood cell volume yielded an $\mathrm{r}^{2}=0.14$. $^{1}$ Therefore, $86 \%$ of the variance in $\dot{\mathrm{VO}}_{2 \max }$ is attributable to factors other than the change in $\mathrm{Hb}_{\text {mass }}$. Further, it is important to be aware that $\mathrm{VO}_{2 \max }$ is not the sole determinant of performance. ${ }^{6}$ Among elite athletes, other factors such as exercise economy and the fractional utilisation of $\dot{\mathrm{VO}}_{2 \max }$ are also important determinants of endurance performance. ${ }^{6}$ In addition to the increase in $\mathrm{Hb}_{\text {mass }}$ and the subsequent increase in near sea-level $\dot{\mathrm{VO}}_{2 \max }$, altitude training can enhance muscle efficiency, probably at a mitochondrial level, and change the muscle proteins involved in acid-base control; it can also increase the capacity for flux of lactate, bicarbonate and hydrogen ions from muscle to blood, all of which can be associated with better performance in endurance athletes and team sport athletes. ${ }^{7} \mathrm{~A}$ detailed review of non-haematological adaptations to hypoxia that can improve near sea-level endurance performance has been published recently. ${ }^{8}$ Given an adequate hypoxic dose (high enough, long enough and for enough hours/day), ${ }^{9}$ there will be an increase in $\mathrm{Hb}_{\text {mass }}, \mathrm{VO}_{2 \max }$ and possibly performance. $^{8}$ However, there is evidence that although altitude training increases $\mathrm{Hb}_{\text {mass, }}$, there may also be a parallel reduction in cardiac output, vascular regulation or some other mechanism that can limit the increase in $\dot{\mathrm{VO}}{ }_{2 \text { max. }}{ }^{10} 11$

When evaluating the increases in $\mathrm{Hb}_{\text {mass }}$ and $\dot{\mathrm{V}} \mathrm{O}_{2 \text { max }}$ resulting from altitude training, factors such as age, sex, training status and type of sport all must be considered. Many research studies have also used small sample sizes and a major strength of the current study is pooling data across many research studies to increase the sample size and to encompass a range of measures across athletes varying in the aforementioned characteristics. Recently, there has also been a controversy about whether altitude training, particular live high-train low (LHTL), is effective in improving $\mathrm{Hb}_{\text {mass }}$, $\dot{\mathrm{V}}_{2 \max }$ and endurance performance. ${ }^{12}$ Therefore, the aim of the current study was to investigate the 
effectiveness of altitude (both live high-train high (LHTH) and LHTL) in increasing $\mathrm{Hb}_{\text {mass }}$ and $\dot{\mathrm{VO}}_{2 \text { max }}$ and the strength of the relationship between changes in $\mathrm{Hb}_{\text {mass }}$ and $\dot{\mathrm{VO}}_{2 \text { max }}$ in a large number of elite endurance athletes from different sports after different forms of altitude training. The substantial number of participants pooled for analysis offers more statistical power than individual smaller studies with modest sample sizes.

\section{METHODS}

\section{Subjects}

The current study used elite endurance athletes from 10 separate studies spanning a 6-year period across four different sports (cycling, running, triathlon and race walking). The study comprised a total of 145 participants (94 males and 51 females), $\dot{\mathrm{V}} \mathrm{O}_{2 \max } 67.7 \pm 7.2(71.9 \pm 4.6$ male and $61.4 \pm 5.9$ female $) \mathrm{mL} /$ $\mathrm{min} / \mathrm{kg}($ mean $\pm \mathrm{SD})$. The participants were at a minimum 'nationally ranked' athletes, but most had represented Australia in international competition. All participants were part of various altitude studies that were approved by the Australian Institute of Sport Ethics Committee. A summary of each of the 10 studies is listed in table 1 .

\section{Experimental overview}

The current study investigated the relationship between changes in $\mathrm{Hb}_{\text {mass }}$ and $\dot{\mathrm{VO}}_{2 \max }$ after various forms of altitude training, with the minimum requirement that both $\mathrm{Hb}_{\text {mass }}$ and $\dot{\mathrm{V}}_{2 \max }$ were measured pre-altitude and post-altitude. The altitude exposures included (1) classical LHTH at various locations (1350-$2700 \mathrm{~m}$ ), (2) simulated LHTL (3000 m, $14 \mathrm{~h} /$ day) in the altitude house at the Australian Institute of Sport (AIS, Canberra, Australian Capital Territory, Australia) or using altitude tents, (3) intermittent hypoxic training (IHT) in the altitude house at the AIS and (4) intermittent hypoxic exposure (IHE) using hypoxic breathing devices. A total of $n=83$ athletes completed altitude training interventions ( 1 and 2 ) and were treated as the Altitude group. The data from control participants and from altitude protocols that would not normally be expected to induce an increase in $\mathrm{Hb}_{\text {mass }}$ (IHE and IHT alone) were $(\mathrm{n}=62)$ all treated as control data. Details of participants, type of altitude, dose of altitude, exposure duration and average $\dot{\mathrm{V}}_{2 \max }$ are presented in table 1 . The studies included were a combination of seven published ${ }^{13-19}$ and three previously unpublished works.

\section{Maximal oxygen uptake}

An incremental protocol to volitional exhaustion was used to determine $\dot{\mathrm{V}}_{2 \max }$. Protocols were specific to each sport and have been described in full previously. ${ }^{13-19}$ Expired ventilation samples were collected using a custom-built open-circuit indirect calorimetry system with associated in-house software for determination of oxygen uptake. ${ }^{20}$ The same open-circuit indirect calorimetry system was used in all studies. Additionally, the typical error (TE, SD of the difference scores divided by $\sqrt{ } 2$ ) for $\mathrm{V}_{2 \max }$ established in our laboratory for this system was $2.1-2.4 \%,{ }^{19}{ }^{21}$ which includes the combination of biological and analytical error.

\section{Haemoglobin mass}

Total $\mathrm{Hb}_{\text {mass }}$ was measured with the optimised 2 min carbon monoxide (CO) rebreathing test adapted from Schmidt and Prommer $^{22}$ for all the studies included in the analysis. Briefly, a CO dose of $\sim 1.2 \mathrm{~mL} / \mathrm{kg}$ body weight was administered and rebreathed for $2 \mathrm{~min}$. Capillary fingertip blood samples were taken before the start of the test and at $\sim 7 \mathrm{~min}$ post administration of the $\mathrm{CO}$ dose. Blood samples were measured a minimum of five times for determination of $\% \mathrm{HbCO}$ using an OSM three hemoximeter (Radiometer, Copenhagen). $\mathrm{Hb}_{\text {mass }}$ was calculated from the mean change in $\mathrm{HbCO}$ before and after rebreathing CO. This parameter was measured prior to the intervention period and within 1 week after the completion of the intervention period. The TE of $\mathrm{Hb}_{\text {mass }}$ was $1.8 \%,{ }^{18} 1.9 \%,{ }^{13}$ $2.0 \%,{ }^{14} 15{ }^{17} 2.2 \%{ }^{19}$ and $2.4 \%{ }^{16}$

\section{Statistical analysis}

A two-tailed Pearson correlation was used to compare the correlation between percentage changes in $\mathrm{Hb}_{\text {mass }}$ and $\dot{\mathrm{V}} \mathrm{O}_{2 \text { max }}$ with statistical significance set at $\mathrm{p}<0.05$. Linear regression analyses were also performed on the percentage changes in $\mathrm{Hb}_{\text {mass }}$ and $\dot{\mathrm{V}} \mathrm{O}_{2 \max }$, and provided a regression equation, goodness of fit $\left(r^{2}\right)$ and significance of the slope ( $p$ value). Analyses were conducted both with the intercept allowed to vary freely and forced through the origin. Linear regression was also conducted for a cross-sectional comparison on the cumulative raw data (pre and post) of $\mathrm{Hb}_{\text {mass }}(\mathrm{g} / \mathrm{kg})$ and $\dot{\mathrm{V}} \mathrm{O}_{2 \max }(\mathrm{mL} / \mathrm{min} / \mathrm{kg})$. All analyses were performed using Prism software (2007) V.5.01 (GraphPad Software Inc., San Diego, California, USA).

\section{RESULTS}

\section{Changes in $\mathrm{Hb}_{\text {mass }}$ and $\mathrm{V}_{2 \max }$}

The correlation between percentage changes in $\mathrm{Hb}_{\text {mass }}$ and $\dot{\mathrm{V}} \mathrm{O}_{2 \max }$ was significant for the altitude and control groups combined, with a slope $(95 \% \mathrm{CI})$ of $0.48(0.30$ to 0.67$)$ when the intercept was free to vary, and a slope of 0.62 (0.46 to 0.77 ) when the intercept was constrained through the origin (figure 1). The correlation was also significant for the altitude and control groups, separately (figure 2). For the altitude group, the slope was 0.57 ( 0.27 to 0.87 ) when free to vary and when constrained through the origin, the slope was 0.72 (0.51 to 0.92 ). The corresponding values for the Control group were 0.32 (0.06 to 0.58$)$ and 0.38 (0.12 to 0.64 ). The Altitude group increased $\mathrm{Hb}_{\text {mass }}$ by $3.3 \pm 3.0 \%$ (mean $\pm \mathrm{SD}$ ) and $\dot{\mathrm{VO}_{2 \max }}$ by $2.7 \pm 4.4 \%$; the corresponding changes in the Control group were $0.8 \pm 3.0 \%$ and $1.1 \pm 3.4 \%$.

\section{Cross-sectional relationship between $\mathrm{Hb}_{\text {mass }}$ and $\mathrm{VO}_{2 \max }$}

When the intercept was able to vary, the linear regression of cumulative raw data (control and altitude, pre and post) of $\mathrm{Hb}_{\text {mass }}$ and $\dot{\mathrm{VO}}_{2 \max }$ was as follows

$$
\dot{\mathrm{V}} \mathrm{O}_{2 \max }(\mathrm{mL} / \mathrm{min} / \mathrm{kg})=3.32 \times \% \mathrm{Hb}_{\text {mass }}(\mathrm{g} / \mathrm{kg})+22
$$

The slope was significant $(p<0.0001, r=0.75)$ with $95 \%$ CI of 2.98 to 3.66. When constrained through the origin, the corresponding slope was 4.94 (4.89 to 4.99; figure 3).

\section{DISCUSSION}

The main findings of the current study were (1) a significant, very large cross-sectional relationship between $\mathrm{Hb}_{\text {mass }}$ and $\dot{\mathrm{V}} \mathrm{O}_{2 \max }$ and (2) a significant, moderate correlation between changes in $\mathrm{Hb}_{\text {mass }}$ and $\dot{\mathrm{V}} \mathrm{O}_{2 \max }$ in a large group of elite endurance athletes undertaking altitude training. Athletes who were part of LHTL and LHTH altitude interventions increased $\mathrm{Hb}_{\text {mass }}$ and $\dot{\mathrm{V}} \mathrm{O}_{2 \text { max }}$ by $\sim 3 \%$ such that each $1 \%$ change in $\mathrm{Hb}_{\text {mass }}$ will result in a $0.6-0.7 \%$ change in $\dot{\mathrm{V}} \mathrm{O}_{2 \max }$. Even though significant, the correlation was weak and explained only $15 \%$ of the variation, indicating that other factors are still important in increasing $\dot{\mathrm{VO}}_{2 \max }$, apart from an increased $\mathrm{Hb}_{\text {mass. }} 15$ 
Table 1 Individual study summary

\begin{tabular}{|c|c|c|c|c|c|c|c|c|}
\hline Year & Sport & Study N (M/F) & Altitude type (N) & Level (m) & Duration (d) & Time at altitude & $\dot{\mathrm{V}} \mathrm{O}_{2 \max }(\mathrm{mL} / \mathrm{min} / \mathrm{kg})$ & Test mode (Ergometer) \\
\hline $2006(13)$ & Cycling & $11(11 / 0)$ & LHTL (11) & 3000 & 21 & $14 \mathrm{~h} /$ day & $65.32 \pm 5.29$ & Cycle (lode bike) \\
\hline 2007 (14) & Cycling & $9(9 / 0)$ & $\begin{array}{l}\text { LHTH (5) } \\
\text { CON (4) }\end{array}$ & 2700 & 21 & 24 h/day & $72.16 \pm 4.66$ & Cycle (lode bike) \\
\hline 2007 (17) & Running & $32(21 / 11)$ & $\begin{array}{l}\text { LHTL (18) } \\
\text { CON (14) }\end{array}$ & 3000 & 21 & $14 \mathrm{~h} /$ day & $71.60 \pm 6.05$ & Run (treadmill) \\
\hline 2008 (18) & Running & $17(13 / 4)$ & $\begin{array}{l}\text { LHTL+TH (8) } \\
\text { IHT (9) }\end{array}$ & $\begin{array}{l}3000+2200 \\
2200\end{array}$ & $\begin{array}{l}21+9 \\
9\end{array}$ & $\begin{array}{l}14 \mathrm{~h} / \text { day+60 } \min \\
60 \mathrm{~min}\end{array}$ & $67.91 \pm 7.47$ & Run (treadmill) \\
\hline 2008 (19) & Walking & $16(8 / 8)$ & $\begin{array}{l}\text { LHTL (6) } \\
\text { CON (10) }\end{array}$ & 3000 & 21 & $14 \mathrm{~h} / \mathrm{d}$ & $62.17 \pm 7.44$ & Race walk (treadmill) \\
\hline $2009(16)$ & Triathlon & $18(14 / 4)$ & $\begin{array}{l}\text { LHTL (5) } \\
\text { IHE (8) } \\
\text { CON (5) }\end{array}$ & $\begin{array}{l}3000 \\
3500-6000\end{array}$ & $\begin{array}{l}17 \\
17\end{array}$ & $\begin{array}{l}14 \mathrm{~h} / \text { day } \\
60 \mathrm{~min}\end{array}$ & $72.49 \pm 4.74$ & Run (treadmill) \\
\hline $2010(15)$ & Cycling & $9(0 / 9)$ & $\begin{array}{l}\text { LHTL (5) } \\
\text { CON (4) }\end{array}$ & 3000 & 26 & $14 \mathrm{~h} /$ day & $62.20 \pm 4.68$ & Cycle (tode bike) \\
\hline 2011 & Walking & $10(4 / 6)$ & $\begin{array}{l}\text { LHTH (5) } \\
\text { CON (5) }\end{array}$ & 1850 & 28 & & $64.98 \pm 6.59$ & Race walk (treadmill) \\
\hline 2011 & Walking & $6(2 / 4)$ & $\begin{array}{l}\text { LHTL (3) } \\
\text { CON (3) }\end{array}$ & 3000 & 28 & $14 \mathrm{~h} /$ day & $60.73 \pm 6.60$ & Race walk (treadmill) \\
\hline 2012 & Walking & $17(12 / 5)$ & $\begin{array}{l}\text { LHTH (7) } \\
\text { LHTH (10) }\end{array}$ & $\begin{array}{l}3000 / 1350 \\
1350\end{array}$ & $\begin{array}{l}21 \\
21\end{array}$ & $\begin{array}{l}9 \mathrm{~h} / \text { day } / 15 \mathrm{~h} / \text { day } \\
24 \mathrm{~h} / \text { day }\end{array}$ & $66.50 \pm 6.17$ & Race walk (treadmill) \\
\hline
\end{tabular}

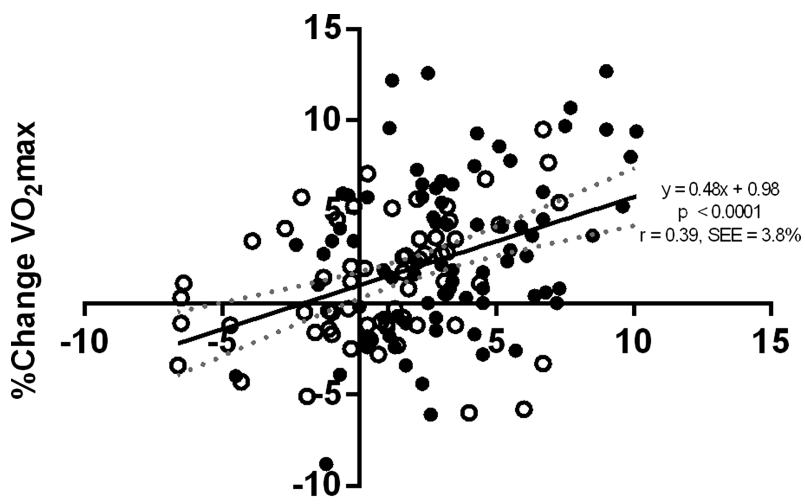

\%Change Hbmass

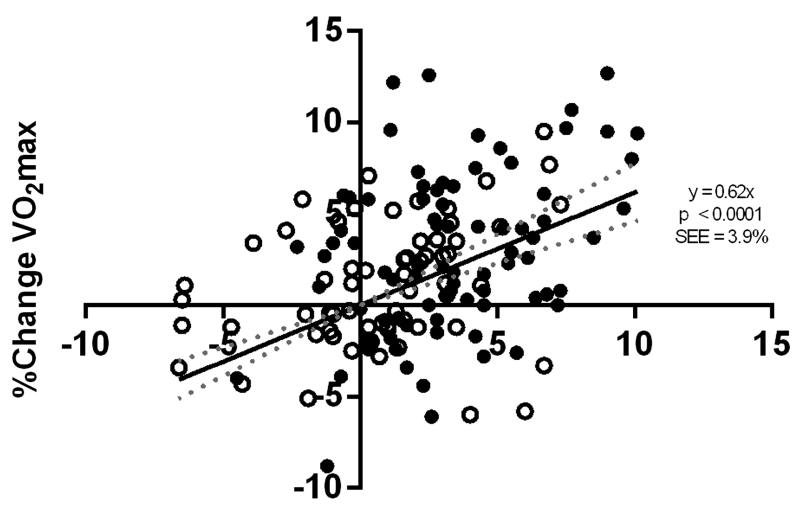

\%Change Hbmass

Figure 1 Linear regression (and $95 \% \mathrm{Cl}$ ) for changes between preintervention and postintervention for $\mathrm{Hb}_{\text {mass }}$ and $\mathrm{VO}_{2 \text { max }}, \mathrm{n}=145$. Regression slope (solid line) and 95\% Cls (dashed line) are shown. Top panel is for intercept free to vary, and bottom panel intercept constrained through the origin. Open circles are control participants and filled circles are altitude participants.
Cross-sectional relationship between $\mathrm{Hb}_{\text {mass }}$ and $\dot{\mathrm{V}} \mathrm{O}_{2 \max }$

The current study yielded a strong relationship between $\mathrm{Hb}_{\text {mass }}$ and $\dot{\mathrm{V}}{ }_{2 \max }(\mathrm{r}=0.75)$, with a slope of $\sim 4.9$ when constrained through the origin; this implies that every additional gram of $\mathrm{Hb}$ will increase $\dot{\mathrm{VO}}_{2 \max }$ by $\sim 4.9 \mathrm{~mL} / \mathrm{min}$. Other cross-sectional studies indicate a similarly strong relationship between $\mathrm{Hb}_{\text {mass }}$ and $\dot{\mathrm{VO}}_{2 \max }$, which is independent of sex or age. ${ }^{23} \mathrm{~A}$ close association between absolute $\mathrm{Hb}_{\text {mass }}$ and $\dot{\mathrm{VO}}_{2 \max }(\mathrm{r}=0.72)$ was reported in 131 males of varying training status. ${ }^{24}$ Likewise, strong correlations between $\mathrm{Hb}_{\text {mass }}$ and $\dot{\mathrm{VO}}_{2 \max }$ have been reported across a range of sports and degrees of training status, with the slope of the regression line $\sim 4$ in each instance, although in the present study the slope is closer to 5 when the regression is forced through the origin. In practical terms, this relationship translates to a change in $\dot{\mathrm{VO}}_{2 \max }$ of $\sim 4-5 \mathrm{~mL} / \mathrm{min}$ for every $1 \mathrm{~g}$ change in $\mathrm{Hb}_{\text {mass. }} 232526$ Furthermore, the relationship is consistent with the theoretical calculation of $\mathrm{O}_{2}$ transport during maximal aerobic exercise. The strong relationship between $\mathrm{Hb}_{\text {mass }}$ and $\dot{\mathrm{V}} \mathrm{O}_{2 \text { max }}$ has two important implications; first, that a high $\mathrm{Hb}_{\text {mass }}$ is an important prerequisite for a high $\mathrm{VO}_{2 \max }{ }^{23}{ }^{27}$ and second, that alterations to $\mathrm{Hb}_{\text {mass }}$ have the potential to alter $\dot{\mathrm{VO}}_{2 \max }$ and possibly performance.

Successful endurance performance is highly correlated with an athlete's $\dot{\mathrm{VO}}_{2 \max .}{ }^{28-32}$ Other physiological and performance factors are important and include sustaining a high percentage of $\dot{\mathrm{VO}}_{2 \max }$ for the event duration (fractional utilisation or lactate threshold) ${ }^{33} 34$ and exercising with relatively low energy expenditure (good economy). ${ }^{30} 3335$ These factors in isolation are not necessarily better predictors of performance than $\dot{\mathrm{V}} \mathrm{O}_{2 \max }$, although in elite athletes where an already high $\dot{\mathrm{VO}}_{2 \max }$ is present, these factors may become more important. A three-factor model $\left(\dot{\mathrm{VO}}_{2 \max }\right.$, running economy, lactate threshold) was reported to highly predict the within-subject changes in performance (measured by peak running speed) during a 17 -week training period in well-trained distance runners. ${ }^{36}$ When holding each variable constant, to ascertain the effect of a predictor variable independently of all the other predictor 

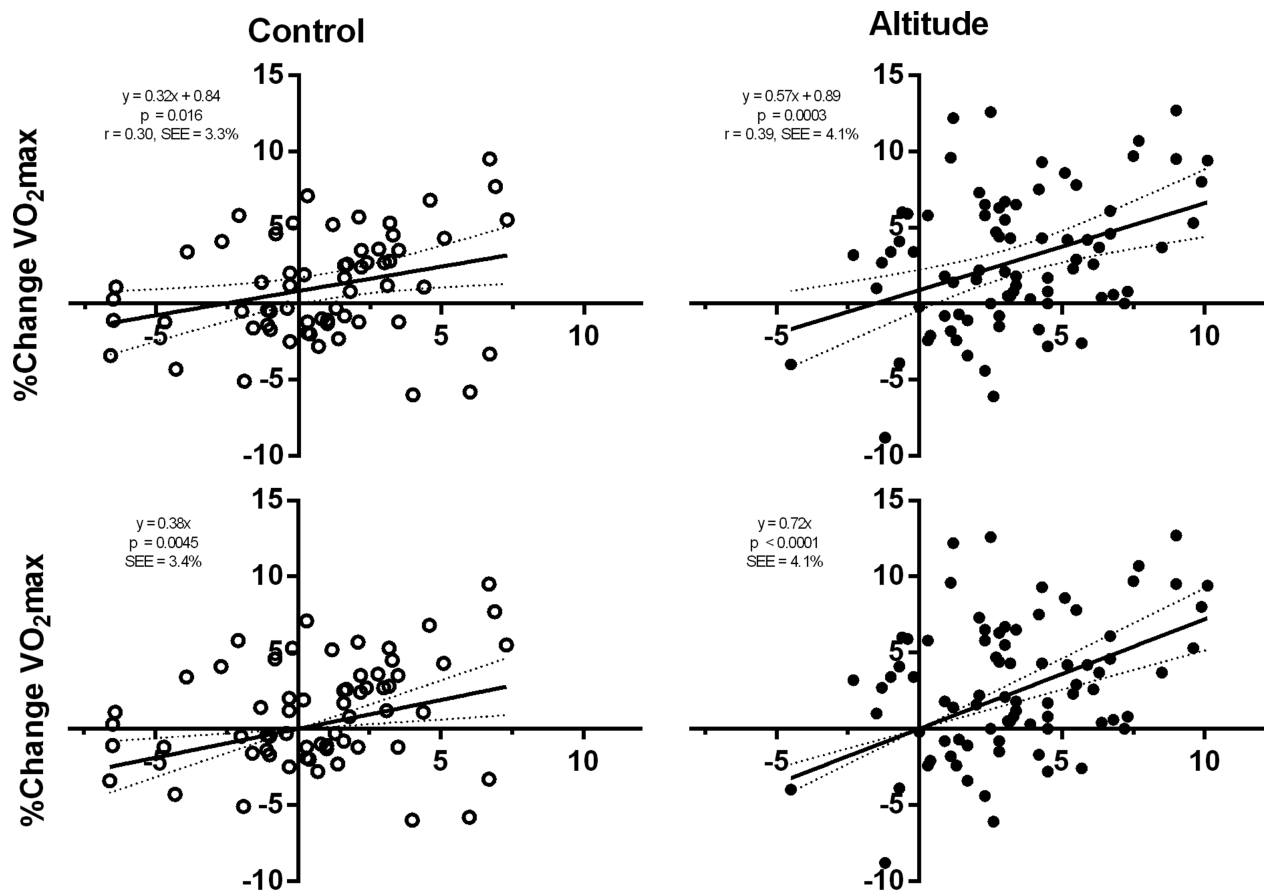

\%Change Hbmass

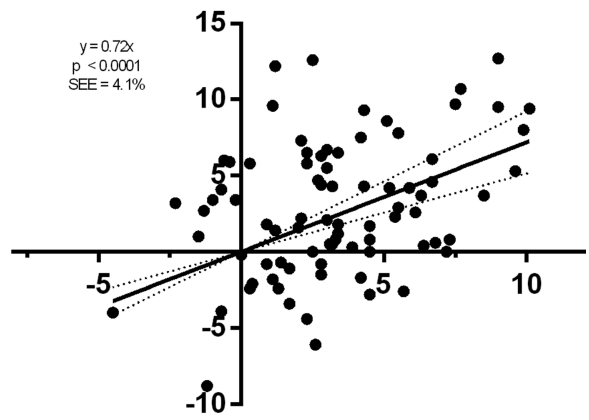

\%Change Hbmass

Figure 2 Linear regression (and $95 \% \mathrm{Cl}$ ) for changes between preintervention and postintervention for $\mathrm{Hb}_{\text {mass }}$ and $\mathrm{V}_{2 \text { max }}$ control $(n=62)$, altitude $(n=83)$. Regression slope (solid line) and $95 \%$ Cls (dashed line) are shown. Top panels are for intercept free to vary, and bottom panels for intercept constrained through the origin. Left-side graphs are control groups (including IHE and IHT alone) and right-side graphs are altitude groups.
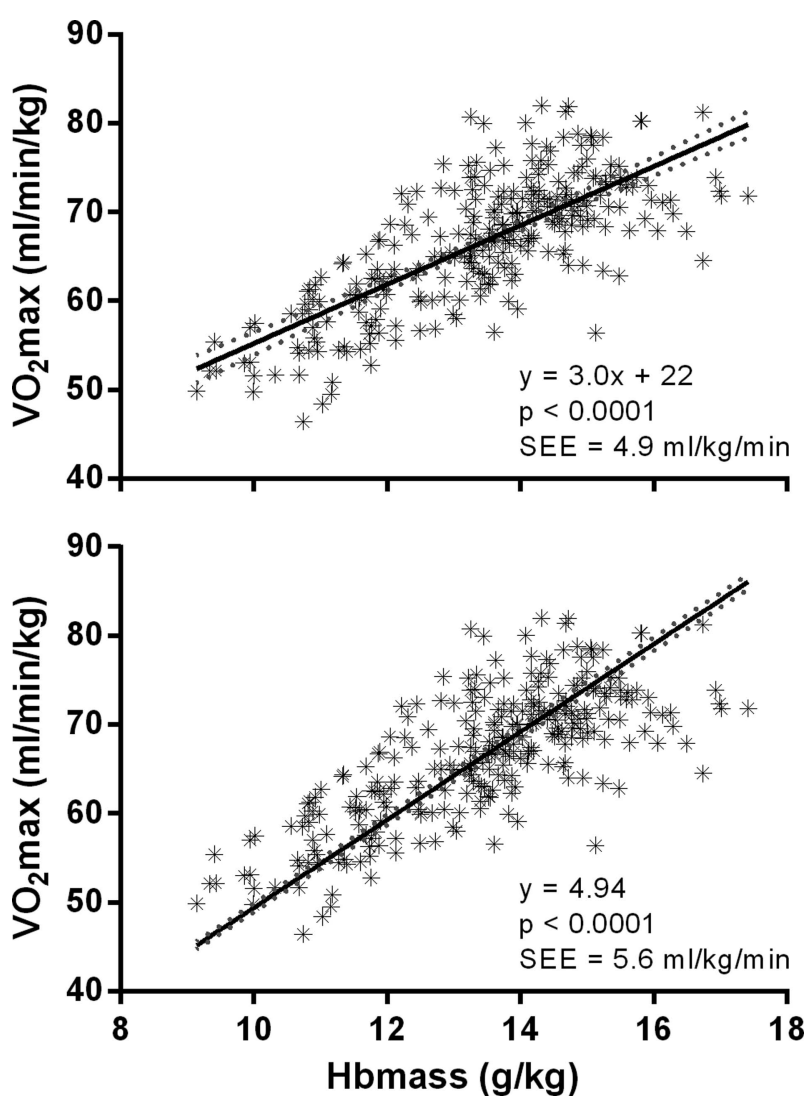

Figure 3 Linear regression between $\mathrm{Hb}_{\text {mass }}$ and $\dot{\mathrm{V}}_{2 \max }$ in raw units. Regression slope (solid line) and $95 \%$ Cls (dashed line) are shown. Data are cumulative for pre-exposure and postexposure to altitude, $n=290$. Top panel is for intercept free to vary, and bottom panel intercept constrained through the origin. variables, $\dot{\mathrm{VO}}_{2 \max }$ was the best predictor of performance with a $1 \%$ improvement in $\dot{\mathrm{VO}}_{2 \max }$ resulting in a $0.5 \%$ improvement in peak running speed, but the running economy was also a moderate predictor of performance. ${ }^{36}$

Changes in $\mathrm{Hb}_{\text {mass }}$ and $\dot{\mathrm{V}}_{2 \max }$

Interestingly, the $\mathrm{Hb}_{\text {mass }}-\dot{\mathrm{VO}}_{2 \max }$ relationship appears to uncouple somewhat following altitude training, with disproportionate changes being reported in $\mathrm{Hb}_{\text {mass }}$ and $\dot{\mathrm{VO}}_{2 \text { max }}$. A weak association $(\mathrm{r}=0.32)$ between changes in $\mathrm{Hb}_{\text {mass }}$ and $\dot{\mathrm{VO}}_{2 \max }$ was reported following 3 weeks of LHTL simulated altitude training combined with hypoxic training. ${ }^{18}$ In fact, when the individual data are examined, some athletes displayed substantial increases in $\mathrm{Hb}_{\text {mass }}(>5 \%)$ with no change in $\dot{\mathrm{V}} \mathrm{O}_{2 \max }$, whereas others who experienced minor reductions in $\mathrm{Hb}_{\text {mass }}$ increased $\dot{\mathrm{V}} \mathrm{O}_{2 \max }$ by $\sim 5 \%{ }^{18}$ Similarly, despite a $\sim 4 \%$ increase in $\mathrm{Hb}_{\text {mass }}$ observed in elite runners following $\sim 400 \mathrm{~h}$ of simulated LHTL ( $\sim 2900 \mathrm{~m}$ ), only a trivial change in $\dot{\mathrm{VO}}_{2 \max }$ was observed and, not surprisingly, the relationship between changes in $\mathrm{Hb}_{\text {mass }}$ and $\dot{\mathrm{V}} \mathrm{O}_{2 \max }$ was also trivial $(\mathrm{r}=0.04) .{ }^{37}$ It has been reported that after 24 days of LHTL, the $\mathrm{Hb}_{\text {mass }}$ increased by $5.3 \%(\sim 44 \mathrm{~g})$ in a group of orienteers, accompanied by a $4.1 \%$ increase in $\dot{\mathrm{V}}{ }_{2 \max }(\sim 145 \mathrm{~mL} / \mathrm{min})$, which in terms of the mean data appears in line with the expected increase in $\dot{\mathrm{VO}}_{2 \max } / \mathrm{g}$ of $\mathrm{Hb}_{\text {mass. }}{ }^{38}$ Indeed, the relationship between the change scores was $\sim 0.7$ when the group was divided into men $(\mathrm{r}=0.75)$ and women $(r=0.68)$; however, when the group data are combined, the relationship becomes much weaker $(r=0.35, p=0.29)$. Clark et $a l^{13}$ report a trivial correlation between changes in $\mathrm{Hb}_{\text {mass }}$ and $\dot{\mathrm{VO}}_{2 \max }$ in well-trained cyclists following 21 days of simulated LHTL $(r=0.09, p=0.32)$; however, the slope of the regression line appears to indicate that a $1 \%$ increase in $\mathrm{Hb}_{\text {mass }}$ is associated with a $0.8 \%$ increase in $\dot{\mathrm{VO}}_{2 \max }$. The only study to report a significant (albeit weak) correlation $(r=0.4, p=0.02)$ 
between changes in red cell volume (measured using Evan's Blue) and $\dot{\mathrm{VO}}_{2 \max }$ was in a group of collegiate runners following 4 weeks of LHTL, where $5 \%$ and $9 \%$ increases in red cell volume and $\dot{\mathrm{VO}}_{2 \max }$ were reported. ${ }^{1}$

The current study suggests that the relationship between increases in $\mathrm{Hb}_{\text {mass }}$ and $\dot{\mathrm{VO}_{2 \max }}$ is slightly stronger in athletes undertaking altitude training compared to control athletes, although the variance explained was $\sim 15 \%$, which is similar to that reported previously $\left(\mathrm{r}^{2}=0.14\right)^{1}$ for a $9 \%$ increase in red cell volume associated with a $5 \%$ increase in $\dot{\mathrm{VO}}_{2 \max }$. When participants $(\mathrm{n}=18)$ received recombinant EPO injections (50 IU/kg $3 \times /$ week) for a period of $25 \mathrm{~d}$, they increased $\dot{\mathrm{VO}}_{2 \max }$ more proportionately with the increase in $\mathrm{Hb}_{\text {mass }}\left(\mathrm{r}^{2}=0.28\right)$ when compared with the current data set, ${ }^{39}$ adding support to this apparent uncoupling of the $\mathrm{Hb}_{\text {mass }}-\dot{\mathrm{VO}}_{2 \max }$ relationship with altitude training. On the other hand, when nonathletic, altitude adapted participants return to near sea-level, they show a $\dot{\mathrm{VO}_{2 \max }}$ similar to lowlanders despite a $13 \%$ increase in $\mathrm{Hb}_{\text {mass. }}{ }^{40}$ The lack of adaptation in $\dot{\mathrm{VO}}_{2 \max }$ during training at hypoxia may be related to impairment in vascular regulation and reduced cardiac output after altitude training. ${ }^{10}{ }^{11}$ Interestingly, 23 consecutive nights of LHTL simulated altitude exposure $(3000 \mathrm{~m})$ depressed $\dot{\mathrm{VO}}_{2 \max }$ by $7 \%$ with only a trivial increase in $\mathrm{Hb}_{\text {mass. }}{ }^{4}$ This, along with other non-haematological adaptations that occur with training at altitude, may explain why $\dot{\mathrm{V}}_{2 \max }$ does not increase more proportionately with the increase in $\mathrm{Hb}_{\text {mass. }}$. Finally, it should be considered that even with a small TE of measurement for $\dot{\mathrm{V}}{ }_{2 m a x}$ and $\mathrm{Hb}_{\text {mass }}$, it is quite likely that in some of the studies with smaller samples, as well as in the current study, these errors contribute to an obfuscation of the relationship between the two. However, the results of the current study are quite likely to be more robust, given the relatively large sample size and hence greater statistical power, as well as using only one method for measuring $\mathrm{Hb}_{\text {mass }}$.

The differences in the changes in the $\mathrm{Hb}_{\text {mass }}-\mathrm{VO}_{2 \max }$ relationship between the altitude and control athletes (figure 2) are most likely a result of individual variation. ${ }^{17}$ However, using the component estimates of TE, the combined error of measurement for changes between successive measures of $\mathrm{Hb}_{\text {mass }}$ and $\dot{\mathrm{VO}}_{2 \max }$ at the $95 \%$ level could be as large as $\sim \pm 8 \%\left(1.96 \times \sqrt{2} \times\left(\sqrt{ }\left(2^{2}+2.2^{2}\right)\right)\right.$, which is a consequence of analytical and biological variation in both tests. Factors such as illness, training (or detraining), fatigue and iron stores may all potentially affect changes in $\mathrm{Hb}_{\text {mass }}$ and $\dot{\mathrm{VO}}_{2 \max \text {. }}{ }^{42}{ }^{43}$ Interestingly, for the control group, there was a scatter of data (for changes in $\mathrm{Hb}_{\text {mass }}$ and $\mathrm{VO}_{2 \max }$ ) about the origin in positive and negative directions suggestive of measurement error, whereas the Altitude group showed a preponderance of points in the positive/positive quadrant for both measures, inferring that altitude is an effective intervention to increase $\mathrm{Hb}_{\text {mass }}$ and

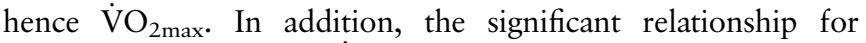
changes in $\mathrm{Hb}_{\text {mass }}$ and $\dot{\mathrm{VO}}_{2 \max }$ found for the Control group most likely reflects not just measurement error but also real changes in these markers secondary to factors such as training/ detraining.

When acutely exposed to hypoxia, it is not just $\dot{\mathrm{VO}}_{2 \max }$ that is affected. All the functional systems of the body are affected, including the central nervous system, respiratory system, cardiovascular system and muscles, a process that is mediated at the tissue level through rapid oxygen sensing. ${ }^{44}$ The transcription factor hypoxia-inducible factor-1 (HIF-1), present in every tissue of the body, is the global regulator of oxygen homeostasis and plays a critical role in the acute cardiovascular and respiratory responses to hypoxia. ${ }^{45}$ Improvement in many of these responses may be a factor in their variable response to increasing $\dot{\mathrm{VO}}_{2 \max }$ after exposure to altitude.
In summary, the current data indicate that increases in $\mathrm{Hb}_{\text {mass }}$ were significantly, albeit weakly, correlated with increases in $\dot{\mathrm{V}} \mathrm{O}_{2 \max }$ in elite endurance athletes after altitude training interventions with an approximate $1 \%$ increase in $\mathrm{Hb}_{\text {mass }}$ resulting in a $0.6-0.7 \%$ increase in $\dot{\mathrm{VO}}_{2 \max }$. However, since the relationship is not perfect, other factors must be considered, which affect changes in $\dot{\mathrm{V}}{ }_{2 \max }$, in addition to other responses from altitude that may impact on performance.

\section{What are the new findings?}

- This study confirms the strong cross-sectional relationship between haemoglobin mass $\left(\mathrm{Hb}_{\text {mass }}\right)$ and maximal oxygen uptake $\left(\mathrm{V}_{2 \text { max }}\right)$ in a sample of 145 elite athletes.

- Adequate moderate altitude exposure is effective for increasing $\mathrm{Hb}_{\text {mass }}$ and $\mathrm{V}_{2 \text { max }}$ in elite endurance athletes by $\sim 3 \%$. But the correlation between these changes is weak and explains less than one-sixth of the variation, indicating that other factors are still important in increasing $\mathrm{V}_{2 \max }$ after altitude training, apart from an increased $\mathrm{Hb}_{\text {mass }}$.

\section{How might it impact on clinical practice in the near}

future?

- Altitude training can be undertaken as a helpful method to improve endurance performance in already highly trained athletes, but it should be incorporated as part of an annual plan.

- Race performance may improve post-altitude as a result of increased haemoglobin mass and maximal oxygen uptake, but other non-haematological factors are also quite likely important. Therefore, altitude training studies should not be limited to measuring these two variables alone.

Acknowledgements The authors would like to acknowledge Dr Sally Clark, Dr Clare Humberstone-Gough, Dr Eileen Robertson, Dr David Martin and Dr David Pyne for their contribution to various studies used for the current manuscript.

Contributors PUS was involved in the conception and design, acquisition of data, analysis, interpretation of data, drafting of the article and approved the final version. $L A G-L$ was involved in the acquisition of data, analysis and interpretation of data, and critically revised the article and approved the final version. WFS was involved in the conception and design, and critically revised the article and approved the final version. CJG was involved in the conception and design, analysis and interpretation of data, and critically revised the article and approved the final version.

\section{Competing interests None.}

Ethics approval Australian Institute of Sport Ethics Committee (for all 10 studies).

Provenance and peer review Not commissioned; externally peer reviewed.

Open Access This is an Open Access article distributed in accordance with the Creative Commons Attribution Non Commercial (CC BY-NC 3.0) license, which permits others to distribute, remix, adapt, build upon this work non-commercially, and license their derivative works on different terms, provided the original work is properly cited and the use is non-commercial. See: http://creativecommons.org/ licenses/by-nc/3.0/

\section{REFERENCES}

1 Levine BD, Stray-Gundersen J. 'Living high-training low': effect of moderate-altitude acclimatization with low-altitude training on performance. J App/ Physiol 1997;83:102-12

2 Levine BD, Stray-Gundersen J, Gore CJ, et al. Point: counterpoint: positive effects of intermittent hypoxia (live high:train low) on exercise are/are not mediated primarily 
by augmented red cell volume. J App/ Physiol 2005;99:2053-5; discussion 2055-2058.

3 Stray-Gundersen J, Chapman RF, Levine BD. 'Living high-training low' altitude training improves sea level performance in male and female elite runners. J App/ Physiol 2001;91:1113-20.

4 Wagner PD. New ideas on limitations to V02max. Exerc Sport Sci Rev 2000;28:10-14.

5 Schmidt W, Heinicke K, Rojas J, et al. Blood volume and hemoglobin mass in endurance athletes from moderate altitude. Med Sci Sports Exerc 2002:34:1934-40.

6 di Prampero PE. The energy cost of human locomotion on land and in water. Int J Sports Med 1986;7:55-72.

7 Billaut F, Gore CJ, Aughey RJ. Enhancing team-sport athlete performance: is altitude training relevant? Sports Med 2012:42:751-67.

8 Gore CJ, Clark SA, Saunders PU. Nonhematological mechanisms of improved sea-level performance after hypoxic exposure. Med Sci Sports Exerc 2007;39:1600-9.

9 Wilber RL. Current trends in altitude training. Sports Med 2001;31:249-65.

10 Favret F, Richalet JP, Henderson KK, et al. Myocardial adrenergic and cholinergic receptor function in hypoxia: correlation with $\mathrm{O}_{2}$ transport in exercise. Am J Physiol Regul Integr Comp Physiol 2001;280:R730-8.

11 Reboul C, Tanguy S, Dauzat M, et al. Altitude negates the benefits of aerobic training on the vascular adaptations in rats. Med Sci Sports Exerc 2005; 37:979-85.

12 Siebenmann C, Robach $\mathrm{P}$, Jacobs RA, et al. 'Live high-train low' using normobaric hypoxia: a double-blinded, placebo-controlled study. J App/ Physiol 2012;112:106-17.

13 Clark SA, Quod MJ, Clark MA, et al. Time course of haemoglobin mass during 21 days live high:train low simulated altitude. Eur J Appl Physiol 2009;106:399-406.

14 Garvican L, Martin D, Quod M, et al. Time course of the hemoglobin mass response to natural altitude training in elite endurance cyclists. Scand J Med Sci Sports 2012;22:95-103

15 Garvican LA, Pottgiesser T, Martin DT, et al. The contribution of haemoglobin mass to increases in cycling performance induced by simulated LHTL. Eur J App/ Physiol 2011:111:1089-101.

16 Humberstone-Gough CE, Saunders PU, Bonetti DL, et al. Comparison of live high: train low altitude and intermittent hypoxic exposure. J Sports Sci Med 2013:112:3275-85.

17 Robertson EY, Saunders PU, Pyne DB, et al. Reproducibility of performance changes to simulated live high/train low altitude. Med Sci Sports Exerc 2010;42:394-401.

18 Robertson EY, Saunders PU, Pyne DB, et al. Effectiveness of intermittent training in hypoxia combined with live high/train low. Eur J Appl Physiol 2010;110:379-87.

19 Saunders PU, Ahlgrim C, Vallance B, et al. An attempt to quantify the placebo effect from a three-week simulated altitude training camp in elite race walkers. Int Sports Physiol Perform 2010;5:521-34.

20 Saunders PU, Telford RD, Pyne DB, et al. Improved running economy in elite runners after 20days of simulated moderate-altitude exposure. J Appl Physiol 2004;96:931-7.

21 Saunders PU, Pyne DB, Telford RD, et al. Reliability and variability of running economy in elite distance runners. Med Sci Sports Exerc 2004;36:1972-6.

22 Schmidt W, Prommer N. The optimized CO-rebreathing method-a new tool to determine total haemoglobin mass routinely. Eur J Appl Physiol 2005;95:486-95.
23 Schmidt W, Prommer N. Impact of alterations in total hemoglobin mass on V02max. Exerc Sport Sci Rev 2010;38:68-75

24 Heinicke $\mathrm{K}$, Wolfarth $\mathrm{B}$, Winchenbach $\mathrm{P}$, et al. Blood volume and hemoglobin mass in elite athletes of different disciplines. Int J Sports Med 2001;22:504-12.

25 Gore CJ, Hahn AG, Burge CM, et al. VO2max and haemoglobin mass of trained athletes during high intensity training. Int J Sports Med 1997;18:477-82.

26 Schmidt W, Prommer N. Effects of various training modalities on blood volume. Scand J Med Sci Sports 2008;18(Suppl 1):57-69.

27 Martino M, Gledhill N, Jamnik V. High VO2max with no history of training is primarily due to high blood volume. Med Sci Sports Exerc 2002;34:966-71.

28 Costill DL. The relationship between selected physiological variables and distance running performance. J Sports Med Phys Fitness 1967;7:61-6.

29 Costill DL, Thomason H, Roberts E. Fractional utilization of the aerobic capacity during distance running. Med Sci Sports 1973;5:248-52.

30 Conley DL, Krahenbuhl GS. Running economy and distance running performance of highly trained athletes. Med Sci Sports Exerc 1980;12:357-60.

31 Saltin B, Astrand PO. Maximal oxygen uptake in athletes. J Appl Physiol 1967:23:353-8.

32 Schabort EJ, Killian SC, St Clair Gibson A, et al. Prediction of triathlon race time from laboratory testing in national triathletes. Med Sci Sports Exerc 2000; 32:844-9.

33 di Prampero PE, Capelli C, Pagliaro $P$, et al. Energetics of best performances in middle-distance running. J Appl Physiol 1993;74:2318-24.

34 Jones AM. The physiology of the world record holder for the women's marathon. Int J Sports Sci Coach 2006:1:101-16.

35 Pollock ML. Submaximal and maximal working capacity of elite distance runners. Part l: cardiorespiratory aspects. Ann N Y Acad Sci 1977;301:310-22.

36 Saunders PU, Cox AJ, Hopkins WG, et al. Physiological measures tracking seasonal changes in peak running speed. Int J Sports Physiol Perform 2010;5:230-8.

37 Saunders PU, Telford RD, Pyne DB, et al. Improved running economy and increased hemoglobin mass in elite runners after extended moderate altitude exposure. J Sci Med Sport 2009;12:67-72.

38 Wehrlin JP, Zuest P, Hallen J, et al. Live high-train low for 24days increases hemoglobin mass and red cell volume in elite endurance athletes. J App/ Physiol 2006;100:1938-45.

39 Parisotto R, Wu M, Ashenden MJ, et al. Detection of recombinant human erythropoietin abuse in athletes utilizing markers of altered erythropoiesis. Haematologica 2001;86:128-37.

40 Prommer $\mathrm{N}$, Heinicke K, Viola T, et al. Long-term intermittent hypoxia increases 02-transport capacity but not VO2max. High Alt Med Biol 2007:8:225-35.

41 Gore CJ, Hahn AG, Aughey RJ, et al. Live high:train low increases muscle buffer capacity and submaximal cycling efficiency. Acta Physiol Scand 2001; 173:275-86.

42 Garvican LA, Martin DT, McDonald W, et al. Seasonal variation of haemoglobin mass in internationally competitive female road cyclists. Eur J Appl Physiol 2010;109:221-31

43 Wachsmuth NB, Volzke C, Prommer N, et al. The effects of classic altitude training on hemoglobin mass in swimmers. Eur J Appl Physiol 2013;113:1199-211.

44 Rusko HK, Tikkanen HO, Peltonen JE. Altitude and endurance training. J Sports Sci 2004:22:928-44; discussion 945.

45 Semenza GL. 02-regulated gene expression: transcriptional control of cardiorespiratory physiology by HIF-1. J App/ Physiol 2004;96:1173-7; discussion 1170-1172. 